\title{
Is Dermoscopy Useful for the Diagnosis of Pseudolymphomas?
}

\author{
Marco Adriano Chessa ${ }^{a}$ Federica Filippi $^{\mathrm{a}}$ Annalisa Patrizi ${ }^{\mathrm{a}}$ Cosimo Misciali ${ }^{\mathrm{a}}$ \\ Guido Collina $^{\mathrm{b}}$ Francesco Savoia $^{\mathrm{a}}$ Alessandro Pileri $^{\mathrm{a}}$ \\ ${ }^{a}$ Dermatology, Department of Experimental, Diagnostic and Specialty Medicine, University of Bologna, Bologna,

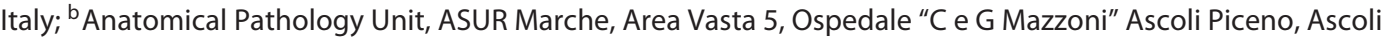 \\ Piceno, Italy
}

\section{Dear Editor,}

Primary cutaneous lymphomas (PCLs) and pseudolymphomas may present with unspecific clinical features, and a large number of skin diseases such as basal cell carcinoma, poorly differentiated squamous cell carcinoma, amelanotic melanoma, and cutaneous metastasis of several solid malignancies should be considered in the differential diagnosis. Geller et al. [1] have shown that clinicians consider PCLs in only $16.3 \%$ of cases in differential diagnosis. Although dermoscopy has been suggested as an aid in the diagnosis of PCLs, the dermoscopic feature of a solitary pink-red nodule in both primary cutaneous B- and T-cell lymphomas has been rarely reported [2-4], while only 5 studies have investigated the dermoscopy of pseudolymphoma, 3 of which have shown images [3, 5-8].

The aim of our study is to compare the dermoscopic features of skin pseudolymphomas and lymphomas in patients with a single erythematous plaque or nodule, in order to identify any possible dermoscopic clues in the differential diagnosis of the two diseases.

M.A. Chessa, F. Filippi, F. Savoia, and A. Pileri contributed equally to this work.

karger@karger.com

(C) 2020 S. Karger AG, Basel

www.karger.com/drm

Karger!
Reviewing our database of the last 10 years, data of 70 patients featuring a single lesion at diagnosis of PCLs or pseudolymphomas were retrieved. We included cases (9 PCLs and 4 pseudolymphomas) with clinical, dermoscopic, histologic data as well as follow-up of at least 24 months (Table 1). At dermoscopy, PCLs revealed constant findings, such as pink-orange color on background (8/9), presence of follicular plugs (4/9), and linear vessels with and without branches (7/9) (Fig. 1a, b).

In the 4 patients with pseudolymphomas, 3 different dermoscopic features were retrieved (Fig. 1c-h): (1) 1 patient showed a homogeneous vascular pattern at the periphery, surrounding a white-orange-colored area with a few follicular plugs in the central part (Fig. 1d); (2) 2 patients presented an orange background color, linear vessels with and without branches and follicular plugs and with perifollicular white color (Fig. 1f); (3) 1 patient had white reticular lines across red globules and red areas and a few linear vessels (Fig. 1h).

Despite the heterogeneous dermoscopy of pseudolymphomas in the literature, in our cases three main dermoscopic features were identified. The first has not been previously reported in the literature to the best of our knowledge. The second was described in pseudolymphomas and also in primary cutaneous B- and T-cell lymphomas 
Table 1. Clinical, dermoscopic and histological findings in our case series

\begin{tabular}{|c|c|c|c|c|c|}
\hline $\begin{array}{l}\text { Patient } \\
\text { No. }\end{array}$ & $\begin{array}{l}\text { Age, } \\
\text { years }\end{array}$ & Sex & Clinical findings & Dermoscopic findings & Histopathological diagnosis \\
\hline 1 & 36 & $\mathrm{~F}$ & $\begin{array}{l}\text { Nodule on the } \\
\text { scalp }\end{array}$ & $\begin{array}{l}\text { Organized lesion orange background; } \\
\text { follicular plugs and linear irregular vessels }\end{array}$ & $\begin{array}{l}\text { Primary cutaneous follicle center } \\
\text { lymphoma }\end{array}$ \\
\hline 2 & 72 & $\mathrm{~F}$ & $\begin{array}{l}\text { Nodule on the } \\
\text { forehead }\end{array}$ & $\begin{array}{l}\text { Yellow-orange background color with few } \\
\text { linear vessels in the left part of the lesion }\end{array}$ & $\begin{array}{l}\text { Primary cutaneous small/medium- } \\
\text { sized pleomorphic T-cell } \\
\text { lymphoproliferative disorder }\end{array}$ \\
\hline 3 & 52 & M & $\begin{array}{l}\text { Plaque on the } \\
\text { abdomen }\end{array}$ & $\begin{array}{l}\text { Short, linear irregular vessels, overlying a } \\
\text { pinkish-orange background }\end{array}$ & $\begin{array}{l}\text { Primary cutaneous small/medium- } \\
\text { sized pleomorphic T-cell } \\
\text { lymphoproliferative disorder }\end{array}$ \\
\hline 4 & 72 & $\mathrm{~F}$ & $\begin{array}{l}\text { Plaque on the left } \\
\text { breast }\end{array}$ & $\begin{array}{l}\text { Short, linear irregular vessels, overlying a } \\
\text { pinkish-orange background }\end{array}$ & $\begin{array}{l}\text { Primary cutaneous small/medium- } \\
\text { sized pleomorphic T-cell } \\
\text { lymphoproliferative disorder }\end{array}$ \\
\hline 6 & 42 & $\mathrm{~F}$ & $\begin{array}{l}\text { Nodule on the } \\
\text { face }\end{array}$ & $\begin{array}{l}\text { Relatively organized lesion with white } \\
\text { reticular lines across orange areas; follicular } \\
\text { plugs and linear irregular vessels }\end{array}$ & $\begin{array}{l}\text { Primary cutaneous follicle center } \\
\text { lymphoma }\end{array}$ \\
\hline 7 & 65 & M & $\begin{array}{l}\text { Nodule on the } \\
\text { neck }\end{array}$ & $\begin{array}{l}\text { Pink structureless areas with unfocused } \\
\text { linear irregular-to-polymorphous vessels }\end{array}$ & $\begin{array}{l}\text { Primary cutaneous CD30 anaplastic } \\
\text { large cell lymphoma }\end{array}$ \\
\hline 8 & 50 & M & $\begin{array}{l}\text { Plaque on the } \\
\text { scalp }\end{array}$ & $\begin{array}{l}\text { White reticular septa divided orange areas } \\
\text { forming a homogeneous cobblestone } \\
\text { pattern }\end{array}$ & $\begin{array}{l}\text { Primary cutaneous follicle center } \\
\text { lymphoma }\end{array}$ \\
\hline 9 & 49 & M & $\begin{array}{l}\text { Nodule on the } \\
\text { scalp }\end{array}$ & $\begin{array}{l}\text { Organized lesion orange background; } \\
\text { follicular plugs and linear irregular vessels }\end{array}$ & $\begin{array}{l}\text { Primary cutaneous follicle center } \\
\text { lymphoma }\end{array}$ \\
\hline 13 & 65 & M & $\begin{array}{l}\text { Nodule on the } \\
\text { scalp }\end{array}$ & $\begin{array}{l}\text { White reticular lines across red globules and } \\
\text { red areas, linear irregular vessels (pattern } 3 \text { ) }\end{array}$ & Pseudolymphoma \\
\hline
\end{tabular}

$[2,5,6,8,9]$. Finally, the third was reported in pseudolymphoma but not in PCLs [3] and recalled the milky-red areas and red globular structures of non-pigmented eccrine poromas [10]. However, the latter shows an additionally polymorphous vascular pattern. In one pseudolymphoma case (patient 10 in Table 1), we observed an evolution from pattern 1 to pattern 2 after 15 days of follow-up.

To conclude, our data shows that a possible overlap between the dermoscopic pattern of PCLs and pseudolymphoma can be detected, reinforcing the concept that a non-invasive diagnostic technique such as dermoscopy should be regarded as an ancillary tool in the differential diagnosis between PCLs and pseudolymphoma. Obviously, the clinicopathological correlation (Fig. 1j, k) after a cutaneous biopsy remains the cornerstone for the diagnosis of both PCLs and pseudolymphoma.

However, dermoscopy can support the clinician in the algorithm for differential diagnosis: granulomatous disorders are characterized by typically orange patches or structureless areas; yellowish nodules surrounded by crown vessels are dermoscopic clues of sebaceous hyper- 

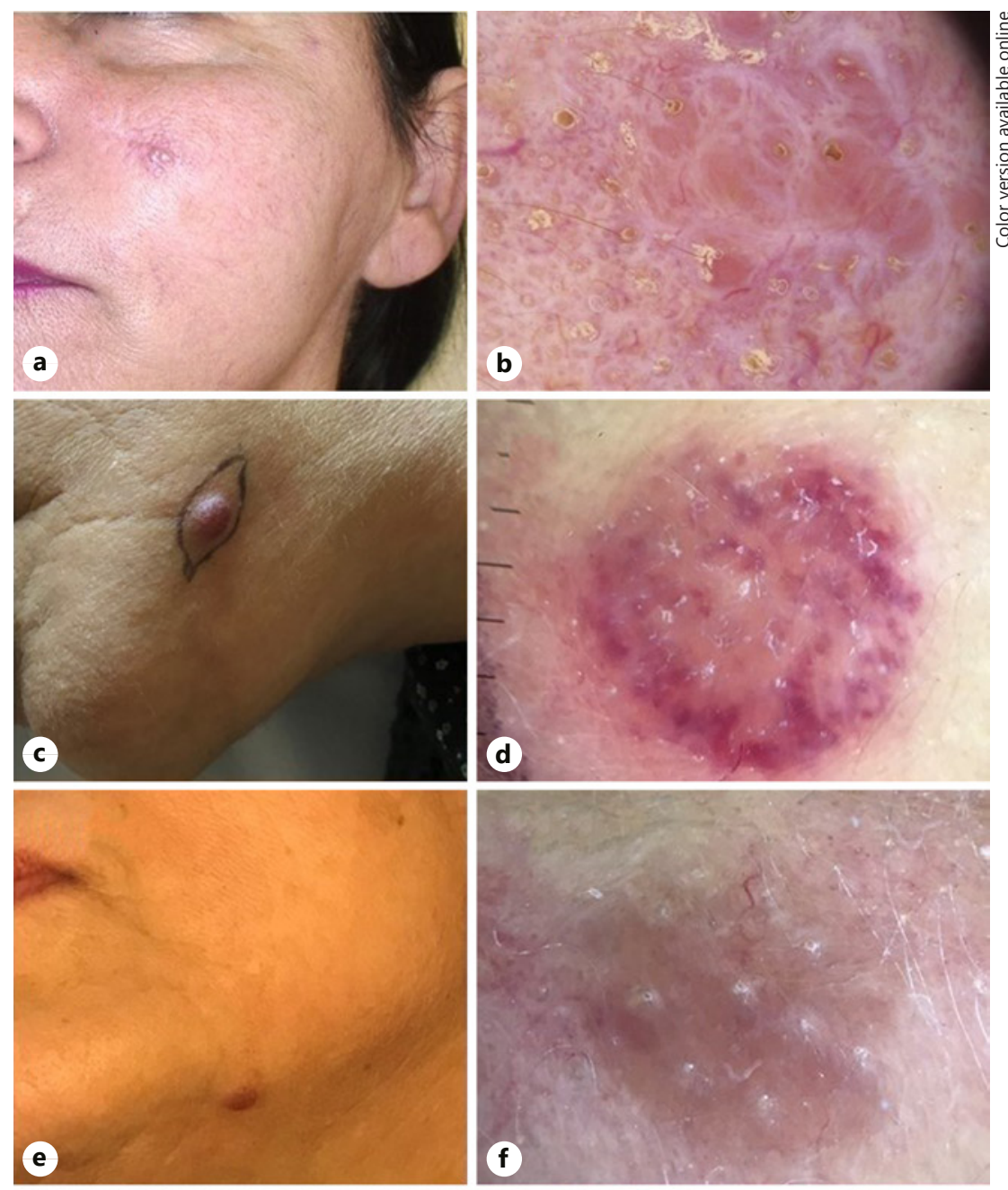
cheek about $1.7 \mathrm{~cm}$ in diameter. b Patient 3 dermoscopy: white reticular septa across orange areas, linear and linear with branches vessels and multiple follicular plugs with perifollicular white color. c Patient 10: nodule $1.2 \mathrm{~cm}$ in diameter on the left mandibular cutaneous areas of the face. d Patient 10 dermoscopy: red unspecific homogenous vascular pattern at the periphery surrounding an orange-colored area with a few follicular plugs in the central part. e Patient 10 after 15 days: nodule about $1 \mathrm{~cm}$ in diameter on the submandibular region. f Patient 10 dermoscopy after 15 days: orange background color, peripheral linear vessels, and follicular plugs with perifollicular white color in the central part. $g$ Patient 13: an asymptomatic plaque about $2 \mathrm{~cm}$ in diameter located in the left frontal region. $\mathbf{h}$ Patient 13 dermoscopy: white reticular lines across red globules and red areas and a few linear vessels. i The epidermis is normal. In the dermis, both superficial and deep, there is a dense lymphocytic infiltrate triangular in shape, where the base parallels the epidermis. $\mathbf{j}, \mathbf{k}$ The infiltrate is composed of a mixed population of lymphocytes showing positivity for CD20 (panel on the left) and $\mathrm{CD} 3$ (panel on the right).
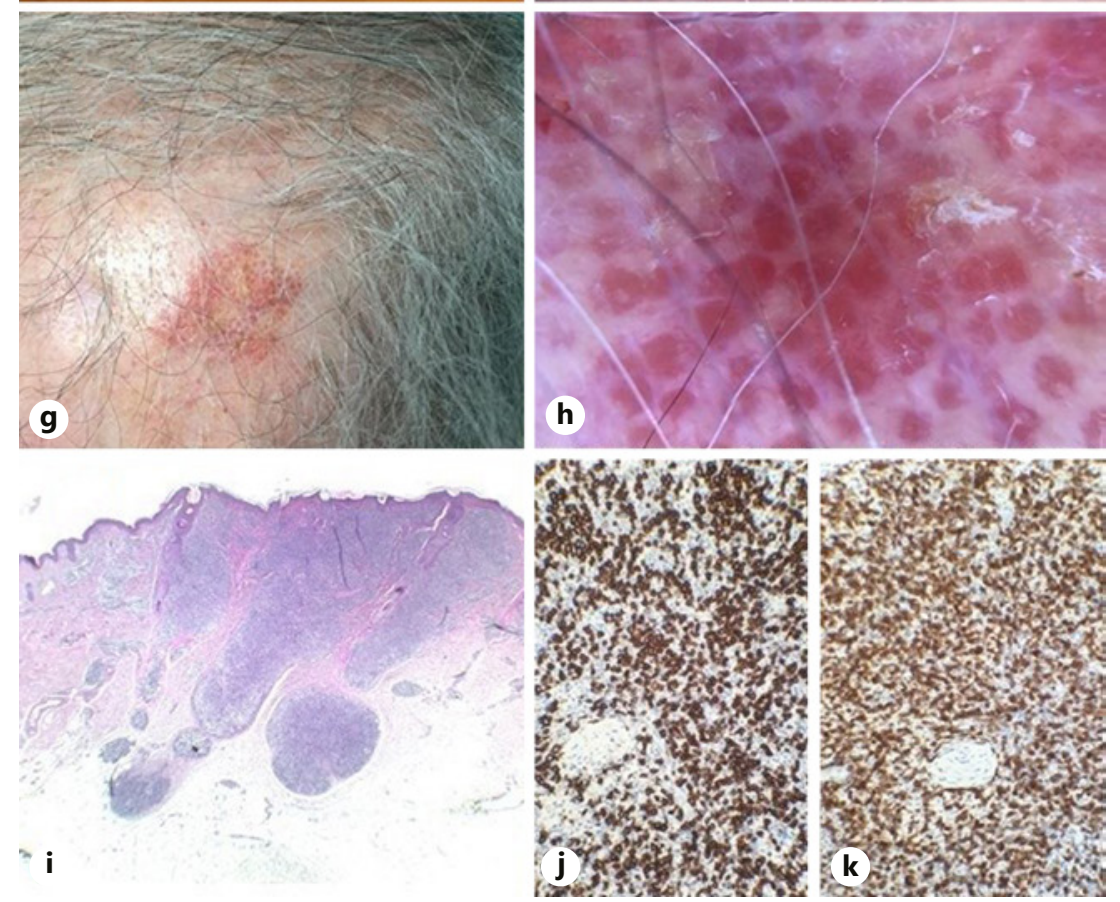
plasia; in basal cell carcinoma (BCC), linear vessels with branches could be found, often associated with other dermoscopy signs such as blue-grey ovoid nests or maple leaf-like areas, while follicular plugs with perifollicular white color are generally not detected in BCC (Fig. 1b).

A possible limitation of our study could be the small sample size, which can be a bias, as well as its retrospective nature. Concerning treatment, in PCLs surgical or radiotherapeutic approaches are the preferred options, while oral doxycycline has been suggested in cases with multiple lesions [11]. In our cases, the 9 PCLs underwent complete surgical excision, and no recurrence was found after at least 24 months of follow-up. The lesions of pseudolymphoma patients resolved following application of high-potency topical steroids (i.e., dipropionate clobetasol $0.05 \%$ ) in accordance with the literature data [3].

\section{Key Message}

Dermoscopy is an ancillary tool in the differential diagnosis between cutaneous lymphomas and pseudolymphoma.

\section{Conflict of Interest Statement}

The authors have no conflicts of interest to declare.

\section{Funding Sources}

None.

\section{Author Contributions}

M.A.C.: Contributed substantially to the conception and design of the study, writing of the manuscript. F.F.: Contributed substantially to the design of the study, writing, acquisition, and interpretation of data. A. Patrizi: Provided critical revision of the article, agreed to be accountable for all aspects of the work in ensuring that questions related to the accuracy or integrity of any part of the work are appropriately investigated and resolved. C.M. and G.C.: Contributed to the acquisition, analysis and interpretation of data, provided critical revision of the article. F.R.: Contributed substantially to the conception and design of the study, provided critical revision of the article. A. Pileri: Contributed substantially to the conception and design of the study, writing, acquisition of data, approval of the version to publish.

\section{Statement of Ethics}

The local Review Board approved the study, and patients provided written consent for the use of the images.

\section{References}

1 Geller S, Marghoob AA, Scope A, Braun RP, Myskowski PL. Dermoscopy and the diagnosis of primary cutaneous B-cell lymphoma. J Eur Acad Dermatol Venereol. 2018 Jan;32(1): 53-6.

2 Pileri A, Agostinelli C, Sabattini E, Tabanelli M, Gaspari V, Leuzzi M, et al. Primary Cutaneous Small/Medium-Sized Pleomorphic Tcell Lymphoproliferative Disorder Shows a Common Vascular Pattern at Dermoscopy. J Eur Acad Dermatol Venereol. 2018 Aug; 32(8):e318-e321.

3 Namiki T, Miura K, Tokoro S, Tanaka M, Yokozeki H. Dermoscopic features of lymphocytoma cutis: A case report of a representative dermoscopic feature. J Dermatol. 2016 Nov; 43(11):1367-8.

4 Piccolo V, Mascolo M, Russo T, Staibano S, Argenziano G. Dermoscopy of primary cutaneous B-cell lymphoma (PCBCL). J Am Acad Dermatol. 2016 Oct;75(4):e137-9.
5 Fujimura T, Hidaka T, Hashimoto A, Aiba S. Dermoscopy findings of pseudolymphomatous folliculitis. Case Rep Dermatol. 2012 May;4(2):154-7.

6 Piccolo V, Russo T, Agozzino M, Vitiello P, Caccavale S, Alfano R, et al. Dermoscopy of Cutaneous Lymphoproliferative Disorders: Where Are We Now? Dermatology. 2018; 234(3-4):131-6.

7 Navarrete-Dechent C, Del Puerto C, Abarzúa-Araya Á, Molgó M, Geller S, Andreani S, et al. Dermoscopy of primary cutaneous Band T-cell lymphomas and pseudolymphomas presenting as solitary nodules and tumors: a case-control study with histopathologic correlation. Int J Dermatol. 2019 Nov; 58(11):1270-1276.

8 Bombonato C, Pampena R, Lallas A, Giovanni P, Longo C. Dermoscopy of Lymphomas and Pseudolymphomas. Dermatol Clin. 2018 Oct;36(4):377-88.
9 Mascolo M, Piccolo V, Argenziano G, Costa C, Lo Presti M, De Rosa G, et al. Dermoscopy Pattern, Histopathology and Immunophenotype of Primary Cutaneous B-Cell Lymphoma Presenting as a Solitary Skin Nodule. Dermatology. 2016;232(2):203-7.

10 Chessa MA, Patrizi A, Baraldi C, Fanti PA, Barisani A, Vaccari S. Dermoscopic-Histopathological Correlation of Eccrine Poroma: An Observational Study. Dermatol Pract Concept. 2019 Oct;9(4):283-91.

11 Alberti-Violetti S, Torres-Cabala CA, Talpur R, Corti L, Fanoni D, Venegoni L, et al. Clinicopathological and molecular study of primary cutaneous $\mathrm{CD} 4+$ small/medium-sized pleomorphic T-cell lymphoma. J Cutan Pathol. 2016 Dec;43(12):1121-30. 